\title{
Pengaruh Penggunaan Cermin Datar dalam Ruang Tertutup pada Sel Surya Silikon
}

\author{
Vony Yumanda dan Satwiko Sidopekso* \\ Jurusan Fisika, Fakultas Matematika dan Ilmu Pengetahuan Alam, \\ Universitas Negeri Jakarta (UNJ) \\ Jl. Pemuda No. 10, Rawamangun, Jakarta 13220
}

\begin{abstract}
Intisari
Upaya mengoptimalkan output listrik pada modul surya dengan cara memaksimalkan intensitas sinar yang jatuh ke permukaan modul surya dengan menggunakan cermin datar (ruang cermin). Hasil yang diperoleh menunjukan terdapat peningkatkan output dari modul surya. Nilai $\mathrm{I}_{s c}, \mathrm{~V}_{o c}$ dan $\mathrm{P}_{\text {out }}$ tertinggi berturut yaitu sebesar 2,13 ampere; 20,483 volt dan 35,34 watt. Sedangkan nilai $\mathrm{I}_{s c}, \mathrm{~V}_{o c}$ dan $\mathrm{P}_{\text {out }}$ tertinggi tanpa ruang cermin berturut yaitu sebesar 0,78 ampere; 19,24 volt dan 12 watt. Prosentase kenaikan daya output pada modul surya dapat mencapai $64,22 \%$, efisiensi tertinggi modul surya pada ruang cermin sebesar $14 \%$ dengan menggunakan daya lampu terendah.
\end{abstract}

KATA KUNCI: modul surya; optimalisasi output listrik; ruang cermin

\section{PENDAHULUAN}

Potensi energi cahaya matahari sebagai sumber energi terbarukan banyak tersedia di alam. Listrik tenaga matahari dibangkitkan oleh komponen yang disebut solar cell. Komponen ini mengkonversi energi dari cahaya matahari menjadi energi listrik.

Sebagai salah satu ukuran performansi sel surya adalah efisiensi. Tetapi pada kenyataannya, effisiensi dari sel surya yang ada saat ini masih rendah. Antara lain sel surya jenis monocrystalline silicon efisiensinya $12-15 \%$, jenis multicrystalline silicon 10-13\%, amorphous silicon 6-9\%. [1]. Untuk itu perlu upaya untuk mengoptimalkan output daya listrik pada modul sel surya, salah satunya dengan cara memaksimalkan intensitas sinar yang jatuh ke permukaan modul surya dengan menggunakan cermin datar.

Dalam mengembangkan sel surya perlu diketahui karakteristik elektrik sel surya bagaimana arus akan berubah dengan berubahnya tegangan keluaran. Karakteristik ini digambarkan oleh kurva arus-tegangan terminalnya (kurva I-V).

Berdasarkan uraian di atas, maka pada penelitian ini akan diamati karakteristik listrik sel surya silikon menggunakan cermin datar yang ditampilkan dalam kurva I-V sehingga dapat diketahui parameter-parameter keluarannya.

\section{DASAR TEORI}

Sifat elektrik dari sel surya dalam menghasilkan energi listrik dapat diamati dari karakteristik listrik sel tersebut, yaitu berdasarkan arus dan tegangan yang dihasilkan sel surya pada kondisi cahaya dan beban yang berbeda-beda. Karakteris-

*E-MAIL: sidopekso61@yahoo.com.au tik ini biasanya digambarkan oleh kurva arus-tegangan terminalnya ( kurva I-V ). Kurva I-V sel surya mempunyai 3 titik utama yaitu arus hubungan singkat $\mathrm{I}_{s c}$ tegangan hubungan tebuka $\mathrm{V}_{o c}$ serta titik daya maksimum P. Hasil tegangan dari sel surya bergantung dari bahan semikonduktor yang dipakai. Jika menggunakan bahan silikon, maka tegangan yang dihasilkan dari setiap sel surya berkisar 0,5 V [2].

Tegangan yang dihasilkan dari sel surya bergantung dari temperatur sel surya, makin besar temperatur tegangan berkurang sekitar 0,0023 volt $/{ }^{\circ} \mathrm{C}$ untuk crystalline silicon atau seki$\operatorname{tar} 0,0028$ volt $/{ }^{\circ} \mathrm{C}$ untuk teknologi thin film. Daya listrik juga mengalami penurunan sampai $0,5 \% /{ }^{\circ} \mathrm{C}$ untuk crystalline silicon atau sekitar $3 \% /{ }^{\circ} \mathrm{C}$ untuk thin film [3]. Untuk arus yang dihasilkan dari sel surya bergantung dari luminasi (kuat cahaya) penyinaran.

Daya sesaat adalah perkalian antara intensitas radiasi matahari yang diterima dengan luas PV modul:

$$
P_{\text {in }}=I_{r} \times A
$$

dengan $\mathrm{P}_{\text {in }}=$ daya Input akibat irradiance matahari (Watt), $\mathrm{I}_{r}=$ intensitas radiasi matahari $\left(\mathrm{Watt} / \mathrm{m}^{2}\right), \mathrm{A}=$ luas area permukaan photovoltaic modul $\left(\mathrm{m}^{2}\right)$. Sedangkan untuk besarnya daya solar cell $\left(\mathrm{P}_{\text {out }}\right)$ yaitu :

$$
P_{\text {out }}=V_{o c} \times I_{s c} \times F F
$$

dengan $\mathrm{P}_{\text {out }}=$ daya yang dibangkitkan oleh sel surya (Watt), $\mathrm{V}_{o c}=$ tegangan rangkaian terbuka pada sel surya (Volt), $\mathrm{I}_{s c}$ $=$ arus hubungan singkat pada sel surya (Ampere), FF $=$ Fill Factor .

Persamaan fill factor ini untuk mengukur bagaimana luasan persegi pada karakteristik I-V suatu sel surya. Harga fill factor ini biasanya sekitar 0,7 sampai 0,85 [4]. Harga fill factor dapat merupakan fungsi $\mathrm{V}_{o c}$. Secara empiris hubungan antara fill factor dengan $\mathrm{V}_{o c}$ adalah :

$$
F F=\frac{V_{o c}-\ln \left(V_{o c}+0,72\right.}{V_{o c}+1}
$$






Gambar 1: Rangkaian pengukuran arus dan tegangan

dengan menggunakan fill factor juga dapat diperoleh efisiensi dari energi sel surya.

$$
\begin{aligned}
\eta & =\frac{V_{m p} \times I_{m p}}{P_{i n}} \\
& =\frac{V_{o c} \times I_{s c} F F}{P_{i n}} \\
& =\frac{P_{\text {out }}}{P_{\text {in }}} \times 100 \%
\end{aligned}
$$

\section{EXPERIMENT}

Pada penelitian ini digunakan modul surya yang terdiri dari 36 sel (9 sel disusun seri dan 4 sel paralel) dimana setiap sel berukuran $(10 \times 10) \mathrm{cm} 2$. Rangkaian pengukuran arus dan tegangan ditunjukkan seperti Gambar 1 .

Prosedur percobaan :

1. Membuat rangkaian pengukuran seperti Gambar 1

2. Mengukur tegangan keluaran modul melalui microcontroler yang hasilnya dapat dibaca langsung melalui PC tanpa dihubungkan dengan beban sehingga didapatkan nilai $\mathrm{V}_{o c}$.

3. Mengukur arus keluaran modul melalui microcontroler yang hasilnya dapat dibaca langsung melalui PC tanpa dihubungkan dengan beban sehingga didapatkan nilai $\mathrm{I}_{s c}$.

4. Menghubungkan rangkaian modul dengan beban serta mengubah-ngubah hambatan beban dari hambatan kecil hingga besar sehingga diperoleh $\mathrm{V}$ dan I

5. Mencatat temperatur disekitar modul sebelum dan sesudah percobaan.

\section{HASIL DAN PEMBAHASAN}

Besar intensitas cahaya secara proposional akan menghasilkan arus yang besar. Seperti gambar berikut, tingkatan cahaya menurun, bentuk dari kurva I-V menunjukkan hal yang sama, kemudian bergerak ke bawah yang

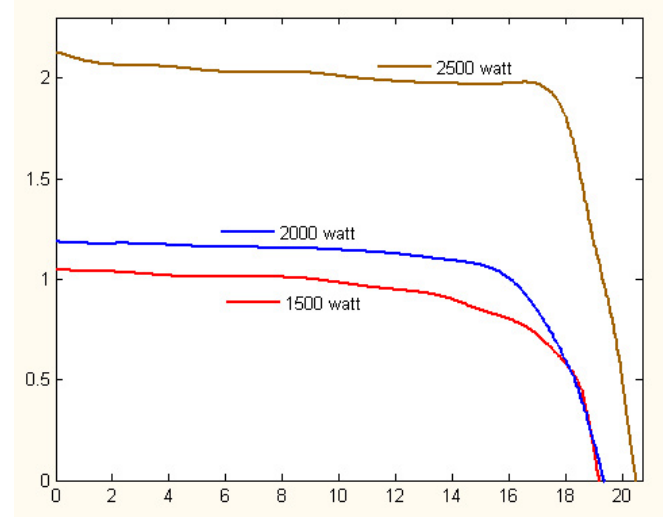

Gambar 2: Kurva karakteristik I-V dengan intensitas $246,4 \mathrm{watt} / \mathrm{m}^{2}$ ; $312,72 \mathrm{watt} / \mathrm{m}^{2}$ dan $643,55 \mathrm{watt} / \mathrm{m}^{2}$ pada jarak $87 \mathrm{~cm}$ dalam ruang kaca

mengindikasikan menurunnya arus dan daya. Voltase tidak banyak berubah oleh bermacam-macam intensitas cahaya.

Hubungan arus (I) dan tegangan keluaran (V) dari sebuah sel surya dalam modul diperoleh dengan mengubah resistansi beban yang mencakup jangkauan luas tertentu, dan dengan memperhatikan jumlah cahaya yang mengenai permukaan sel tersebut. Karaktersistik I-V yang ditunjukkan pada kurva Gambar 2 diamati saat modul disinari oleh sumber lampu Halogen yang diletakkan tegak lurus terhadap permukaan modul pada jarak $87 \mathrm{~cm}$.

\section{A. Daya Output Modul Surya}

Berdasar Persamaan (2) dan (3), nilai fil factor modul surya untuk masing-masing instensitas lampu adalah:

a. $246,4 \mathrm{watt} / \mathrm{m} 2$ adalah 0,8

b. $312,72 \mathrm{watt} / \mathrm{m} 2$ adalah 0,8

c. $643,55 \mathrm{watt} / \mathrm{m} 2$ adalah 0,81

sehingga besarnya daya output dari modul surya:

a. $246,4 \mathrm{watt} / \mathrm{m} 2$ adalah 16,05 watt

b. $312,72 \mathrm{watt} / \mathrm{m} 2$ adalah 18,27 watt

c. $643,55 \mathrm{watt} / \mathrm{m} 2$ adalah $35,34 \mathrm{watt}$

Perbedaan perlakuan terhadap besar intensitas yang diterima modul mempengaruhi keluaran arus yang dihasilkan modul. Sehingga daya yang dihasilkan pun akan meningkat.

\section{B. Efisiensi Modul Surya}

Seberapa besar energi cahaya dari lampu halogen yang dapat diubah menjadi energi listrik dapat diketahui dari efisiensi konversi sel tersebut, dan besarnya didapatkan:

246,4 watt/m2: $\eta=14 \%$

312,72 watt/m2: $\eta=12,56 \%$

$642,55 \mathrm{watt} / \mathrm{m} 2: \eta=11,8 \%$

Dari data di atas kita dapat melihat bahwa efisiensi modul surya semakin berkurang dengan bertambahnya intensitas ca- 




(a)

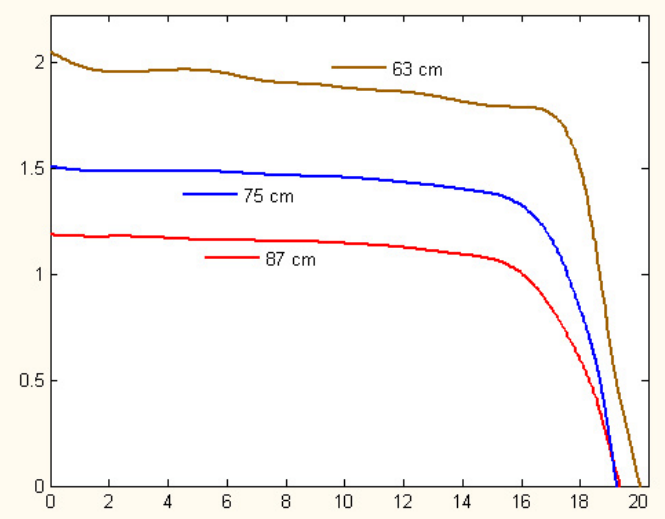

(b)

Gambar 3: Kurva karakteristik I-V (a). pada ruang cermin, (b).tanpa ruang cermin

haya yang digunakan, itu disebabkan karena semakin panasnya ruang kaca dan modul surya akibat penggunaan intensitas yang semakin besar. Lampu halogen yang digunakan memiliki suhu yang tinggi sehingga semakin besar intensitas yang digunakan semakin tinggi pula suhunya dan itu menyebabkan modul surya menjadi panas sehingga menurunkan kinerjanya.

\section{Perbandingan Hasil Pengukuran Output Modul Surya}

Output modul surya yang disinari menggunakan intensitas $312,72 \mathrm{watt} / \mathrm{m}^{2}$ pada jarak $87 \mathrm{~cm}, 75 \mathrm{~cm}$ dan $63 \mathrm{~cm}$ dengan menggunakan cermin datar (ruang cermin) sebagai pemantul cahaya dan yang tanpa menggunakan cermin datar. Dari kurva di atas terlihat perbedaan output modul surya yang dihasilkan, pada kurva Gambar 3, $\mathrm{V}_{o c}$ dan $\mathrm{I}_{s c}$ jauh meningkat dibandingkan pada kurva Gambar 4 dengan meningkatnya $\mathrm{V}_{o c}$ dan $\mathrm{I}_{s c}$ tentu akan meningkat pula $\mathrm{P}_{\text {output }}$ yang dihasilkan.

Dari diagram di atas dapat dilihat kenaikan daya output yang dihasilkan. Daya output modul surya yang menggu- nakan ruang cermin sebagai media peningkat intensitas yang masuk ke modul jauh lebih tinggi dibandingkan dengan daya output yang tanpa menggunakan ruang cermin. Persentase ke-



Gambar 4: Diagram perbandingan daya output modul surya dengan intensitas $312,72 \mathrm{watt} / \mathrm{m}^{2}$

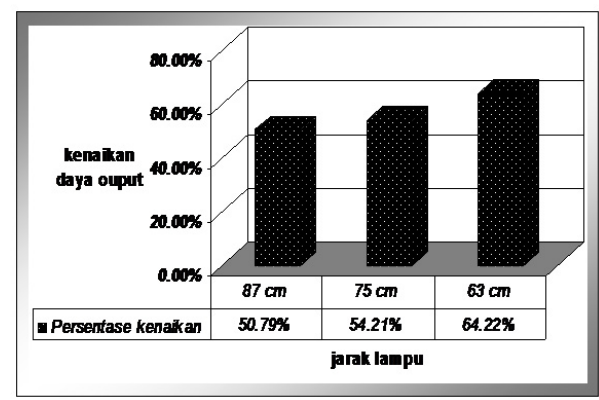

Gambar 5: Diagram persentase kenaikan daya output modul surya dengan intensitas $312,72 \mathrm{watt} / \mathrm{m}^{2}$

naikan daya output modul surya dapat dilihat pada diagram dibawah ini.

Cermin datar berfungsi untuk meningkatkan intensitas cahaya yang jatuh ke modul surya. Dengan menggunakan ruang cermin kita bisa meminimalisir cahaya yang lolos sehingga dapat meningkatkan output pada modul surya.

\section{SIMPULAN}

Secara umum dapat disimpulkan bahwa output modul surya yang menggunakan ruang cermin lebih tinggi dibandingkan tanpa ruang cermin meskipun lampu yang digunakan adalah lampu monokromatik (lampu halogen) yaitu lampu yang memiliki sinar yang tidak dapat diuraikan lagi menjadi komponen warna seperti cahaya matahari, dan output yang dihasilkan pun hampir mendekati spesifikasi yang terdapat pada panel. 
[1] Arianti, Erna, Studi Eksperimen Karakteristik Arus-Tegangan Sel Surya Silikon, Skripsi,Jurusan Pendidikan Fisika, Fakultas Matematika dan Ilmu Pengetahuan Alam, Universitas Negeri Jakarta,2000

[2] Halim, Abdul, Photovoltaic power system: Harapan dan Kenyataan Dimensi Waktu Sains Dan Teknologi (ISEECS, 2001)

[3] Sungkono, Wijoyo, Upaya peningkatan kapasitas daya output photovoltaic melalui proses pendinginan, Universitas Kristen Petra,Surabaya, 2000.

[4] Wibowo, Hariyanto, Studi penggunaan solar reflector untuk optimalisasi output daya pada photovoltaic ( $p v)$, Universitas Kristen Petra,Surabaya, 2009. 